\title{
$\mathrm{t}(16 ; 21)(\mathrm{pll} ; \mathrm{q} 22)$ 및 $T L S / F U S-E R G$ 접합 전사체를 동반한 급성골수백혈병 2 예
}

\author{
장웅린 ${ }^{1} \cdot$ 박일중 $^{1} \cdot$ 이현우 ${ }^{2} \cdot$ 박준성 $^{2} \cdot$ 김효철 $^{2} \cdot$ 김현주 $^{3} \cdot$ 한재호 $^{4} \cdot$ 조성란 $^{1}$ \\ 아주대학교 의과대학 진단검사의학교실', 종양혈액내과학교실 ${ }^{2}$, 의학유전학교실 ${ }^{3}$, 병리학교실 ${ }^{4}$
}

\section{Two Cases of Acute Myeloid Leukemia with t(16;21)(p11;q22) and TLS/FUS-ERG Fusion Transcripts}

\author{
Woong Rin Chang, M.D. ${ }^{1}$, Il Joong Park, M.D. ${ }^{1}$, Hyun Woo Lee, M.D. ${ }^{2}$, Joon Seong Park, M.D. ${ }^{2}$, Hugh Chul Kim, M.D. ${ }^{2}$, \\ Hyon Joo Kim, M.D. ${ }^{3}$, Jae Ho Han, M.D. ${ }^{4}$, and Sung Ran Cho, M.D. \\ Departments of Laboratory Medicine', Hematology-Oncology ${ }^{2}$, Medical Genetics ${ }^{3}$ and Pathology ${ }^{4}$, Ajou University School of Medicine, \\ Suwon, Korea
}

\begin{abstract}
Many AML-associated chromosomal abnormalities, such as t(8;21), t(15;17), inv(16), t(9;11), t(9;22) and $t(6 ; 9)$ are well known. The chromosomal aberration of $t(16 ; 21)(p 11 ; q 22)$ in AML is rare and it is known to be associated with poor prognosis, young age (median age, $22 \mathrm{yr}$ ), and involvement of various subtypes of the French-American-British classification. We report here $2 \mathrm{AML}$ patients with $\mathrm{t}(16 ; 21)(\mathrm{p} 11 ; \mathrm{q} 22)$, proved by conventional cytogenetics and/or reverse transcription (RT)-PCR. Erythrophagocytosis by leukemic blasts was observed in both of the cases. One patient was a $24 \mathrm{yr}-\mathrm{old}$ male with acute myelomonocytic leukemia. His karyotype was 46,XY,t(16;21)(p11;q22),del(18)(p11.2) and RT-PCR revealed the TLS/FUS-ERG fusion transcripts. Although he received allogeneic peripheral blood stem cell transplantation after the first remission, he died 9 months after the initial diagnosis due to relapse of the disease and graft-versus-host disease. The other patient was a $72 \mathrm{yr}-\mathrm{old}$ male with acute myeloid leukemia without maturation. His karyotype was 45,XY,-16,add(21)(q22) and the presence of $\mathrm{t}(16 ; 21)(\mathrm{p} 11 ; \mathrm{q} 22)$ was detected by RT-PCR. He was transferred to another hospital with no more follow-up. We suggest that the presence of $t(16 ; 21)(p 11 ; q 22)$ and/or TLS/FUSERG fusion transcripts has to be considered in cases of AML with erythrophagocytosis. (Korean $J$ Lab Med 2009;29:390-5)
\end{abstract}

Key Words : Acute myeloid leukemia, t(16;21)(p11;q22), Erythrophagocytosis, TLS/FUS-ERG

\section{서 론}

급성골수백혈병(AML)에서 동반되는 염색체 이상 중 $\mathrm{t}(16 ; 21)$ (p11;q22)는 드물게 나타나는 염색체 재배열로서, 만성골수백 혈병(CML)의 모세포 위기 및 급성림프모구백혈병(ALL)에서도

Received: January 29, 2009

Manuscript No : KJLM2228

Revision received: August 10, 2009

Accepted : August 24, 2009

Corresponding author: Sung Ran Cho, M.D.

Department of Laboratory Medicine, Ajou University School of

Medicine, San-5 Wonchon-dong, Yeongtong-gu, Suwon

443-721, Korea

Tel : +82-31-219-5780, Fax : +82-31-219-5778

E-mail : sungran@ajou.ac.kr
각각 1 예씩 보고되어 있다[1, 2]. 이 염색체 이상에 관여하는 유 전자는 16번 염색체의 p11의 TLS/FUS 유전자와 21번 염색체 의 q22에 있는 $E R G$ 유전자로서, 두 유전자 사이에 재조합이 일어나 4종의 접합 전사체를 생산한다 [3, 4].

$\mathrm{t}(16 ; 21)(\mathrm{p} 11 ; \mathrm{q} 22)$ 를 동반한 $\mathrm{AML}$ 의 진단 당시의 나이는 1 세 에서 61세까지 다양하지만 그 중앙값은 22 세로 AML 전체 집단 의 발병 연령에 비하면 젊은 편이고, 남녀 발병 비율의 차이는 보이지 않는다[5]. AML 중 M3를 제외한 모든 아형에서 보고되 어 있으며, 그 중 M2와 M5가 가장 흔하다. 이 염색체 이상이 동반된 $\mathrm{AML}$ 은 항암치료에 잘 반응하지 않고, 예후가 나쁜 것 으로 알려져 있다[5-7]. 
최근 저자들은 염색체 검사 및 역전사 중합효소연쇄반응법 (reverse transcription-PCR, RT-PCR)에 의해 t(16;21)(p11; q22) 및 TLS/FUS-ERG 접합 전사체가 확인된 AML 2예를 경 험하였기에 문헌 고찰과 함께 보고하는 바이다.

\section{증 례}

\section{1. 증례 1}

24 세 남자 환자는 1 개월간 운동 시 호흡 곤란이 있었던 중, 어 지럼증까지 발생하여 타 종합병원에 내원, 시행한 검사에서 $\mathrm{Hb}$ $3.9 \mathrm{~g} / \mathrm{dL}$, 혈소판 $8,000 / \mu \mathrm{L}$ 로 심한 빈혈과 혈소판감소증을 보 여, 더 자세한 검사를 위해 본원으로 전원되었다. 본원 입원 당 시 계통 검진상 어지러움과 호흡 곤란 외에 특이 증상 보이지 않 았고, 이학적 검사상 혈압이 $150 / 80 \mathrm{mmHg}$ 로 약간 높았으며, 체온이 $37.6^{\circ} \mathrm{C}$ 로 경한 열 이외에, 림프절종대나 간비종대는 보 이지 않았다.

주요 검사 소견은 Table 1 과 같았고, 골수 검사에서는 골수아 세포가 유핵세포의 58\%를 차지하였고 Auer rod 음성이었으며 골수아세포의 $26 \%$ 가 세포질에 적혈구를 포식하거나 다수의 공 포를 포함하고 있었다(Fig. 1A). 세포충실성은 $70 \%$ 였고, 뚜렷한 골수세포 형성이상이나 골수섬유화는 관찰되지 않았다. GTG 결합법을 이용한 골수 염색체 검사에서 $46, \mathrm{XY}, \mathrm{t}(16 ; 21)(\mathrm{p} 11$; q22), del(18)(p11.2)의 핵형을 보였다(Fig. 2A). 또한 HemaVision kit (Bio-Rad Laboratories, Hercules, CA, USA)를 이 용한 multiplex RT-PCR 검사에서도 t(16;21)(p11;q22) 양성 이었고, TLS/FUS-ERG 융합 유전자의 A형과 B형 접합전사체 에 해당하는 띠를 보였으며, Kong 등[5]이 사용한 시발체를 이
용하여 추가로 시행한 RT-PCR 검사에서도 $\mathrm{A}$ 형과 $\mathrm{B}$ 형 띠가 관찰되었다(Fig. 3).

분자유전 검사방법을 요약하면 다음과 같다. 환자의 골수 세 포에서 RNA를 추출한 후 $\mathrm{cDNA}$ 를 합성하였고, HemaVision 키트에 포함된 8개의 선별용 시발체 세트를 사용하여 제조사 권

Table 1. Clinical and hematological characteristics of $2 \mathrm{AML}$ patients with $t(16 ; 21)(p 11 ; q 22)$

\begin{tabular}{|c|c|c|}
\hline No. Case & 1 & 2 \\
\hline Age/sex & $24 / \mathrm{M}$ & 72/M \\
\hline Subtype & $\begin{array}{c}\text { Acute myelomonocytic } \\
\text { leukemia }\end{array}$ & $\begin{array}{l}\text { AML without } \\
\text { maturation }\end{array}$ \\
\hline Survival (months) & 9 & $1+^{*}$ \\
\hline $\mathrm{WBC}(/ \mu \mathrm{L})$ & 7,700 & 2,300 \\
\hline $\mathrm{Hb}(\mathrm{g} / \mathrm{dL})$ & 4.5 & 8.5 \\
\hline Platelets ( $/ \mu \mathrm{L})$ & 10,000 & 124,000 \\
\hline \multicolumn{3}{|l|}{$\%$ Blasts } \\
\hline Peripheral blood & 84 & 29 \\
\hline Bone marrow & 58 & 48 \\
\hline Immunophenotype & CD13 (46) & CD13 (30) \\
\hline \multirow[t]{4}{*}{ (\% positive cells) } & CD14 (23) & CD33 (75) \\
\hline & CD33 (89) & CD34 (76) \\
\hline & CD34 (66) & CD61 (20) \\
\hline & HLA-DR (40) & HLA-DR (21) \\
\hline \multicolumn{3}{|l|}{ Cytochemical stain } \\
\hline SBB & + & - \\
\hline PAS & - & - \\
\hline ANBE & + & - \\
\hline \multicolumn{3}{|c|}{$\begin{array}{l}\text { Immunohistochemical } \\
\text { stain (additional) }\end{array}$} \\
\hline CD56 & - & - \\
\hline MPO & ND & + \\
\hline vWF & ND & - \\
\hline
\end{tabular}

*Follow-up was not possible after one month.

Abbreviations: WBC, white blood cells; SBB, Sudan black B; PAS, periodic acid-Schiff; ANBE, $\alpha$-naphtyl butyrate esterase; MPO, myeloperoxidase; vWF, von Willebrand factor; ND, not done.
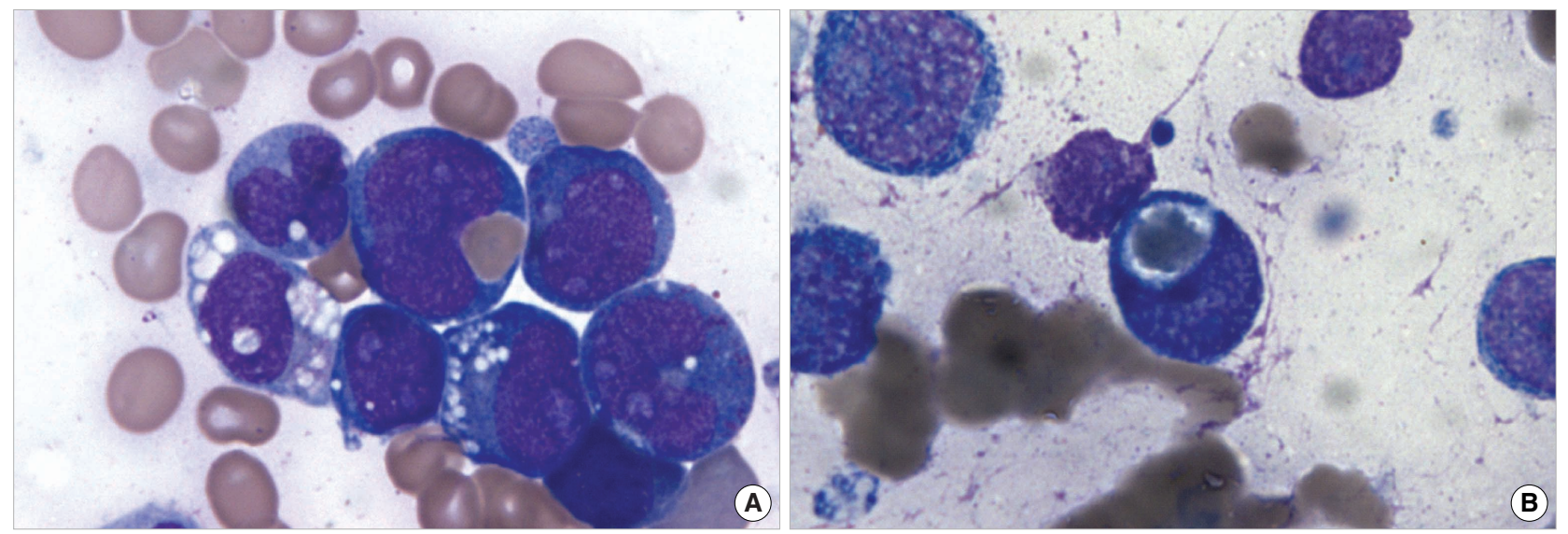

Fig. 1. Bone marrow smears of case $1(A)$ and case $2(B)$ showing blast cells with erythrophagocytic activity and cytoplasmic vacuoles (Wright-Giemsa stain, × 1,000). 


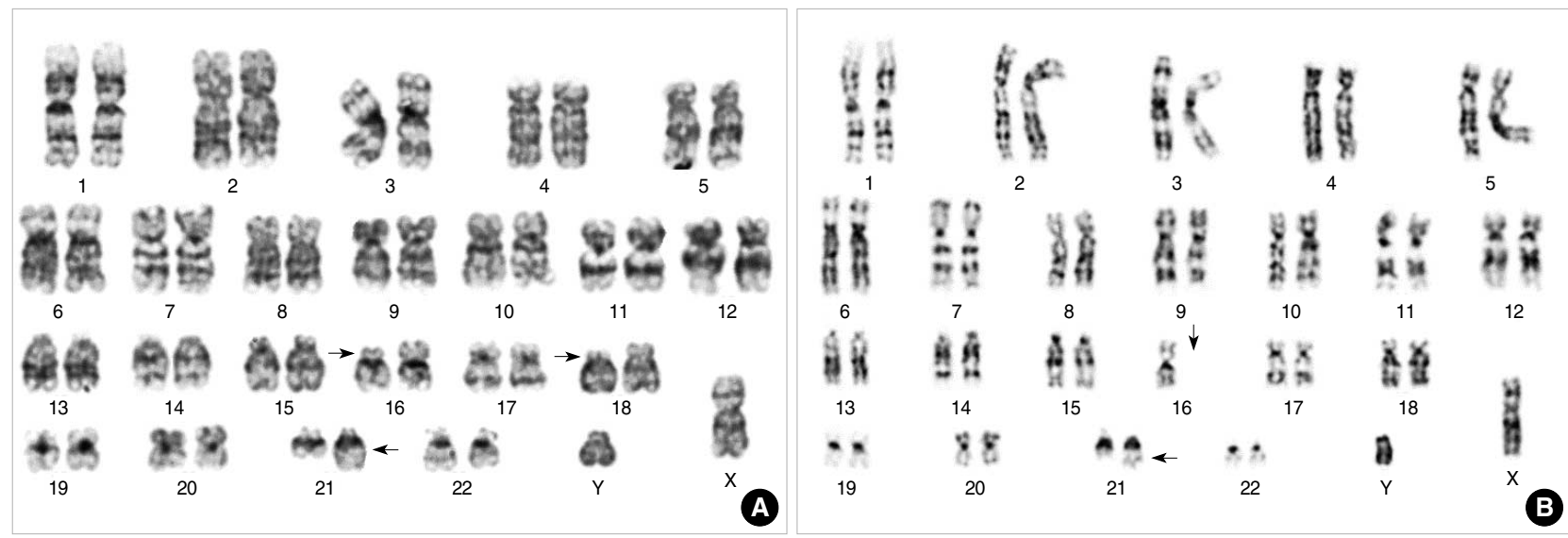

Fig. 2. Karyograms of the patients presented. (A) Case 1 showing 46,XY,t(16;21)(p11;q22),del(18)(p11.2). (B) Case 2 showing 45,XY, -16, add(21)(q22). Arrows indicate rearranged and abnormal chromosomes.
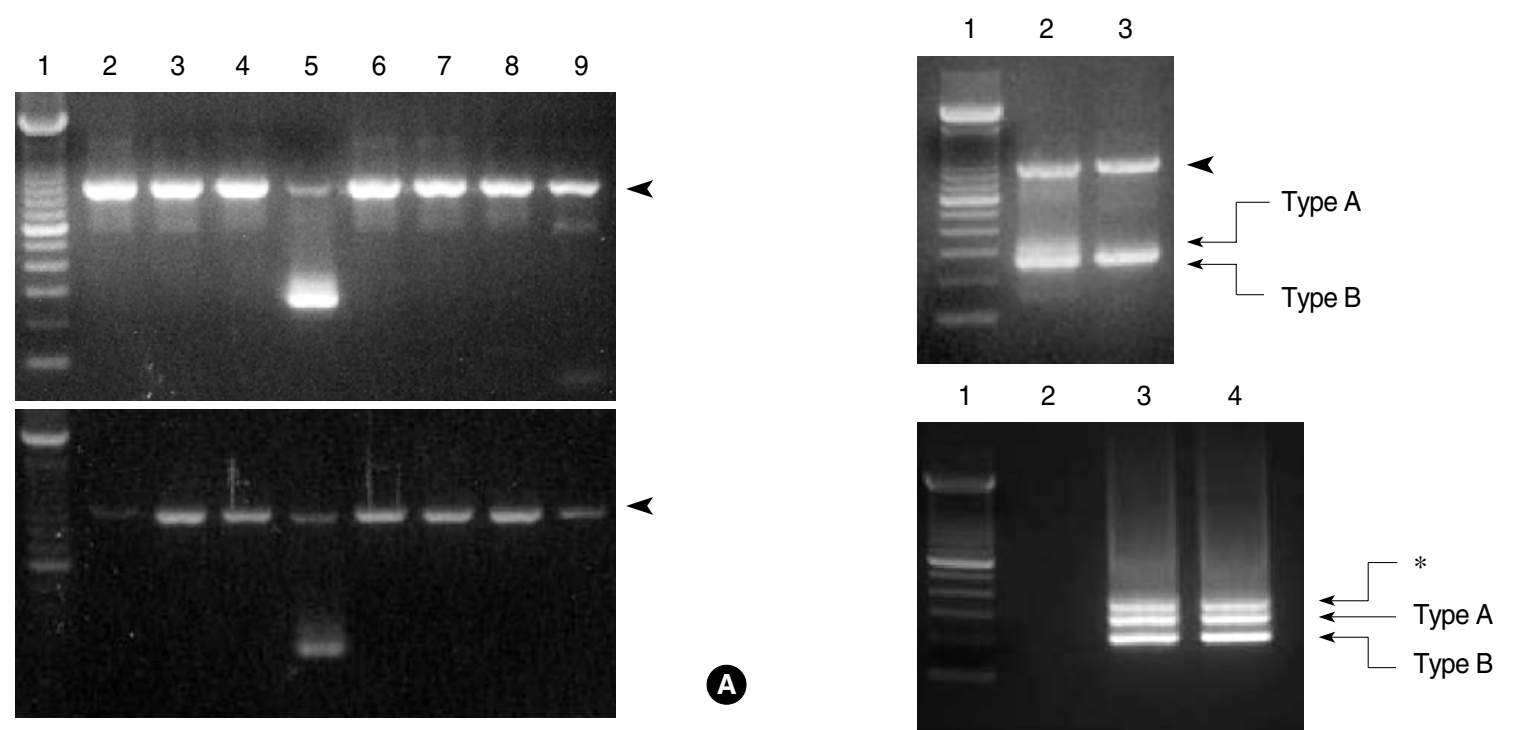

Fig. 3. (A) Multiplex RT-PCR using HemaVision kit in case 1 (upper) and case 2 (lower). Both show an internal control band (911 bp, arrowhead) in each lane and 2 unknown bands (1 strong, 1 weak) in lane 5. (B) RT-PCR for t(16;21)(p11;q22) using HemaVision split-out PCR kit. Both cases show bands for the internal control (911 bp, arrowhead) and the TLS/FUS-ERG fusion transcripts of type A (313 bp) and type B (269 bp). Lane 1, 100 bp ladder; lane 2, case 1; lane 3, case 2. (C) RT-PCR for t(16;21)(p11;q22) using the primers reported by Kong, et al. Both cases have type A (255 bp), type B (211 bp), and an extra band (*). Lane 1, 100 bp ladder; lane 2, negative control; lane 3, case 1; lane 4, case 2.

장사항에 따라 1 차 및 2 차 $\mathrm{PCR}$ 을 시행한 후 전기영동으로 띠가 보이는지 확인하였다. 띠가 관찰되면 해당하는 split-out용 시 발체 세트를 사용하여 1차 및 2차 PCR을 시행한 후 전기영동으 로 띠의 유무와 크기를 확인하였다. 1 차 $\mathrm{PCR}$ 반응은 $95^{\circ} \mathrm{C} 30$ 초, $58^{\circ} \mathrm{C} 30$ 초, $72^{\circ} \mathrm{C} 1$ 분 30 초의 조건으로 25 회 반복하였고, 2 차 $\mathrm{PCR}$ 반응은 동일한 조건으로 20 회 반복하였다. 또한, 동일한 $\mathrm{cDNA}$ 를 대상으로 Kong 등[5]이 제시한대로 5'-CTATGGACAGCAGGACCGTG-3'과 5'-CATAGTAGTAACGGAGGGCG-3'시발체를 사용하여 1차 PCR을, 5'-GGTGGCTAT-
GAACCCAGAGG-3'과 5'-CCTCGTCGGGATCCGTCATC$3^{\prime}$ 시발체를 사용하여 2차 $\mathrm{PCR}$ 을 시행한 후 전기영동하여 띠의 유무와 크기를 확인하였다. 1 차 $\mathrm{PCR}$ 반응은 $94^{\circ} \mathrm{C} 1$ 분, $60^{\circ} \mathrm{C}$ 1 분, $72^{\circ} \mathrm{C} 2$ 분의 조건으로 40 회 반복하였고, 2 차 $\mathrm{PCR}$ 반응은 동일한 조건으로 35 회 반복하였다.

환자는 t(16;21)(p11;q22)를 동반한 급성골수단핵구백혈병(acute myelomonocytic leukemia)으로 진단되었고, cytarabine 및 idarubicin으로 관해유도화학요법을 받았다. 화학요법 28 일 째 실시한 골수 검사에서는 완전관해 소견을 보였고, 염색체 검 
사에서도 $46, \mathrm{XY}$ 의 정상 핵형을 보였다. 환자는 진단 2 개월 및 4 개월 후 각각 1 차 및 2 차 공고화학요법으로 idarubicin과 cytarabine을 투여받았고, 진단 5 개월 후 동종 말초혈액조혈모세포 이식을 받았다. 조혈모세포이식 1개월 및 2 개월 후 시행한 골수 검사에서 골수아세포가 각각 $8 \%, 62 \%$ 로 재발 소견을 보였고, 전신에 홍반성 구진 및 반점이 생기는 등 이식편대숙주 반응을 보였다. 이후 공여자 림프구주입술 및 면역억제 치료를 받았으 나, 이식편대숙주 반응이 점점 더 심해져서, 결국 최초 진단 후 약 9 개월 만에 급성폐부종, 급성신부전, 급성간기능부전, 하부 위장관 출혈로 인해 사망하였다.

\section{2. 증례 2}

72 세 남자 환자는 내원 1 주일 전부터, 근육통, 기침, 가래 등 이 있어서 타 병원에서 실시한 검사상 범혈구 감소증을 보여, 더 자세한 검사를 위해 본원에 입원하였다. 골다공증 및 백내장 외 에 특이 과거 병력은 없었으나, 사회력상 매일 소주 2 병을 50 년 간 마셔왔으며, 매일 담배 1갑씩을 5-60년간 피어왔다. 이학적 검사상 혈압이 $140 / 90 \mathrm{mmHg}$ 로 약간 높은 것 외에는 간비종대 등의 특이 소견은 보이지 않았고, 흥부 엑스선촬영에서 심비대 및 미미한 흥막삼출액이 관찰되었다.

주요 검사 소견은 Table 1 과 같았고, 골수 검사에서는 골수아 세포, 호중구-전골수구가 각각 유핵세포의 $48 \%, 4 \%$ 를 차지하였 고 Auer rod 음성이었으며 골수아세포의 29\%에서 세포질 내 적 혈구 포식이나 공포가 관찰되었다(Fig. 1B). 세포충실성은 $40 \%$ 였 고, 중등도의 적혈구계 형성이상이 관찰되었으나 다른 골수세포 형성이상이나 골수섬유화는 관찰되지 않았다. 골수 염색체 검사 에서 45,XY,-16, add(21)(q22)[14]/46,XY[6]의 섞임증(mosaicism)을 나타내었는데(Fig. 2B), multiplex RT-PCR에서는 $\mathrm{t}(16 ; 21)(\mathrm{p} 11 ; \mathrm{q} 22)$ 양성이었고, TLS/FUS-ERG 융합 유전자의 $\mathrm{A}$ 형과 B형 접합 전사체에 해당하는 띠를 보였으며, Kong 등[5] 이 사용한 시발체를 이용한 RT-PCR 검사에서도 A형과 B형 띠 가 관찰되었다(Fig. 3).

환자는 미분화형급성골수백혈병(acute myeloid leukemia without maturation)으로 진단되었으나, 환자 및 보호자가 타 병원으로 전원 원하여 본원에서 치료하지 않고 퇴원하여, 더 이 상의 추적 관찰이 불가능하였다.

\section{고 찰}

AML에서 동반되는 t(16;21)(p11;q22)는 염색체 16p11의 TLS/
FUS 유전자의 $5^{\prime}$ 부분이 염색체 $21 q 22$ 의 $E R G$ 유전자의 $3^{\prime}$ 부 분과 결합, TLS/FUS $E R G$ 융합 유전자를 형성하여 4종류의 접합 전사체 $(\mathrm{A}, \mathrm{B}, \mathrm{C}, \mathrm{D}$ 형)를 생산한다. 이 중에서 $\mathrm{A}$ 형과 $\mathrm{C}$ 형은 out-of-frame 접합 전사체이지만, B형과 D형은 in-frame 접합 전사체여서 TLS/FUS-ERG 키메라 단백(chimeric protein)을 만든다[5]. A, B, C형은 alternative splicing에 의한 산 물일 가능성이 높고, D형은 B형과 완전히 다른 위치의 breakpoint를 가진 것으로 추정된다[4, 5]. RT-PCR을 이용한 접합 전사체 분석 결과가 보고된 23예[4,5,7] 중 20예에서 $\mathrm{A}, \mathrm{B}, \mathrm{C}$ 형이 동시에 양성이었고, $\mathrm{B}$ 형은 진하고 $\mathrm{A}, \mathrm{C}$ 형은 약한 띠로 관 찰되었다. 나머지 3 예는 $\mathrm{D}$ 형만 양성이었는데 이 중 1 예가 국내 증례[7]였다. 본 증례에서는 2예 모두 $\mathrm{A}, \mathrm{B}$ 형이 양성이었고 $\mathrm{C}$ 형 과 D형은 관찰되지 않았다. HemaVision 키트에 포함된 시발체 를 사용한 경우는 $\mathrm{B}$ 형은 진하고 $\mathrm{A}$ 형은 약한 띠로 관찰되었고 (Fig. 3B), 기존 보고에서 사용된 시발체를 쓴 경우는 A, B형 모두 진한 띠로 관찰되었고 이 외에 한 개의 띠가 더 관찰되었 다(Fig. $3 \mathrm{C}$ ). 추가로 관찰된 띠의 크기는 A형보다 크고 D형보다 는 작아서 $\mathrm{A}, \mathrm{B}, \mathrm{C}$ 형처럼 alternative splicing에 의한 산물일 것으로 추측된다. 또한 기존 보고된 시발체가 본 키트보다 더 뚜렷한 띠를 보인 것은 시발체 종류, $\mathrm{PCR}$ 반응횟수, 시발체 간 의 경쟁 유무 등의 차이에 의한 것이 아닐까 한다.

TLS/FUS-ERG 융합 유전자나 그 산물인 TLS/FUS-ERG 키메라 단백이 백혈병을 유발하는데 어떤 역할을 하는지는 아직 명확히 밝혀지지 않았다. TLS/FUS-ERG 키메라 단백은 Ewing sarcoma를 일으키는 EWS-ERG 키메라 단백과 매우 유사하 고, TLS/FUS 단백이 RNA를 인식하는 모티프 군(motif family)의 하나로서 핵과 세포질에 있는 RNA와 결합한다고 알려져 있다[6]. 또한 TLS/FUS는 BCR-ABL 종양단백에 의한 백혈병 발생(leukemogenesis)의 조절인자 중 하나로 작용하여, 성장 인자에 대한 비의존성을 촉진하고 사이토카인 수용체의 발현 조 정을 통해서 일어나는 분화를 방해한다는 가설이 제시되었다[8]. 한편, TLS/FUS-ERG 키메라 단백이 만들어지면서 ERG의 downstream에 있는 ETS DNA-binding domain이 TLS/FUS 의 $\mathrm{COOH}$ 말단에 있는 RNA 결합 모티프를 대체하여 TLS/FUS 의 NH2 말단에 결합함으로써 전사 활성인자로 작용한다는 주 장도 있다[9].

Imashuku 등[6, 10]은 t(16;21)(p11;q22)를 동반한 AML (t(16; 21)-AML) 환자 8명의 골수도말 표본에서 백혈병 아세포의 0.2$36.7 \%$ 가 다양한 수의 공포를 세포질에 함유하고 있거나 적혈 구, 적혈모구, 림프구, 혈소판 등을 포식한 것을 관찰하고, 백혈 병 세포에 의한 혈구 포식증이 t(16;21)-AML의 특징 중 하나라 
고 제시하였다. 국내에서는 Choi 등[7]이 t(16;21)-AML 환자 1 명의 골수도말 표본에서 골수아세포의 $8 \%$ 가 적혈구나 공포, 포 식소체 등을 세포질에 함유한 것을 보고하였다. 본 증례에서도 2 명 모두 세포질에 적혈구를 포식하고 있거나 공포를 함유하고 있는 아세포가 각각 $26 \%, 29 \%$ 관찰되어, 백혈병 세포에 의한 혈구 포식증이 t(16;21)-AML에서 흔한 소견임을 확인할 수 있 었다.

또한 Shikami 등[11]과 Jekarl 등[12]은 각각 3 명과 12 명의 t(16;21)-AML 환자에서 유세포분석법을 사용하여 CD56 양성 임을 보고하여 CD56 양성이 t(16;21)-AML의 또 하나의 특징 임을 제시하였다. 그러나 본 증례에서는 유세포분석법은 실시하 지 못하였고, 면역조직화학염색법으로 추가검사를 시행한 결과 2 명 모두 CD56 음성이었다. 한편, 증례 2의 경우 유세포분석법 으로 CD61 (20\%) 양성이어서 급성거핵모구성백혈병(acute megakaryoblastic leukemia)으로 생각하였으나 추가검사에 서 myeloperoxidase 양성, von willebrand factor 음성으로 나와 미분화형급성골수성백혈병으로 최종진단하였다. 아세포 표면에 부착된 혈소판으로 인해 CD41, CD61 등의 혈소판 표지 자가 양성으로 잘못 해석될 수 있으므로 주의해야 하겠다[13].

지금까지 보고된 예 중 약 $60 \%$ 에서는 t(16;21)(p11;q22)가 단 독 염색체 이상이었고, 추가적인 염색체 이상 중 $+10,+8, \operatorname{del}(9 \mathrm{q}) /$ -9 가 각각 $10 \%$ 정도를 차지한다[14]. Choi 등[7]이 보고한 증례 는 +10 가 동반되어 있었고, 본 증례의 증례 1 은 $\operatorname{del}(18 \mathrm{p})$ 가, 증 례 2 는 전좌로 파생된 16 번 염색체의 결실로 추정되는 -16 가 동반되어 있었다. 특히 증례 2 의 경우 FISH나 RT-PCR 등의 분자유전학적 방법을 사용하지 않으면 t(16;21)(p11;q22)의 존재 를 간과할 수 있으므로 염색체 결과 판독 시 주의가 필요하고, 조금이라도 의심스러운 경우에는 분자유전학적 방법을 사용하 여 확인하는 것이 좋겠다.

$\mathrm{t}(16 ; 21)-\mathrm{AML}$ 의 예후는 매우 불량하여 생존기간 중앙값이 16-22개월에 불과하다[5, 7]. Kong 등[5]은 TLS/FUS-ERG 유전자의 접합 전사체가 완전관해 상태에서도 존재할 경우, 항 암치료에 의해 t(16;21)(p11;q22)를 가지고 있는 백혈병 세포가 완전히 사라지지 않은 것을 뜻하며, 이러한 경우 첫 번째 관해 시 조혈모세포이식과 같은 더욱 강력한 치료를 고려할 것을 제 안하였다. 증례 1 에서 화학요법 후 완전관해를 보였을 때의 골 수 핵형은 정상이었으나 TLS/FUS-ERG 접합 전사체를 추적 검사하지는 못하였다. 그러나 이후 동종 말초혈조혈모세포이식 을 받았음에도 불구하고 재발한 것으로 보아 t(16;21)(p11;q22) 를 가지고 있는 백혈병 세포가 남아있었던 것으로 판단되고, 항 암치료 후 TLS/FUS-ERG 접합 전사체 검사를 최소잔류질환
검출에 활용하고 그 결과에 따라 치료 방침을 세밀하게 조정하 는 추가적인 연구가 필요하다고 생각된다.

\section{요 약}

급성골수백혈병과 연관된 염색체 이상은 $\mathrm{t}(8 ; 21), \mathrm{t}(15 ; 17)$, $\operatorname{inv}(16), \mathrm{t}(9 ; 11), \mathrm{t}(9 ; 22)$ 와 $\mathrm{t}(6 ; 9)$ 등을 포함하여 많이 알려져 있 다. 급성골수백혈병에서 $\mathrm{t}(16 ; 21)(\mathrm{p} 11 ; \mathrm{q} 22)$ 는 흔하지 않은 염색 체 이상으로, 나쁜 예후, 젊은 발병 나이, 다양한 $\mathrm{FAB}$ 분류에서 의 발병 등의 특징을 보인다. 저자들은 전통적인 세포유전학적 방법 또는 reverse transcription-PCR (RT-PCR)로 검증된 $\mathrm{t}(16 ; 21)(\mathrm{p} 11 ; \mathrm{q} 22)$ 를 동반한 급성골수백혈병 환자 2명을 보고하 였다. 두 증례 모두에서 백혈병 세포에 의한 적혈구포식(erythrophagocytosis)이 관찰되었다. 첫 번째 환자는 24세의 남자 로 급성골수단구백혈병으로 진단되었고, 골수 염색체 검사에서 46,XY,t(16;21)(p11; q22), del(18)(p11.2)의 핵형을 보였으며, RT$\mathrm{PCR}$ 에서 TLS/ FUS-ERG 접합 전사체 양성이었다. 이 환자는 첫 번째 관해 후 동종 말초혈조혈모세포이식을 받았으나, 재발 및 이식편대숙주 반응이 발생하여 최초 진단 후 9 개월 만에 사망 하였다. 다른 한 명은 72 세 남자 환자로 미분화형급성골수백혈병 으로 진단받았고, 골수 염색체 검사상 $45, \mathrm{XY},-16, \operatorname{add}(21)(\mathrm{q} 22)$ 를 보였으나, RT-PCR에 의해 t(16;21)(p11;q22)가 있음을 확인 할 수 있었다. 이 환자는 치료를 시작하기 전 다른 병원으로 전원 되어 더 이상 추적 관찰할 수 없었다. 적혈구포식을 동반한 $\mathrm{AML}$ 환자에서는 t(16;21)(p11;q22)의 존재를 의심해야 하고, 필요한 경우 $\mathrm{RT}-\mathrm{PCR}$ 로 $\mathrm{TLS} / \mathrm{FUS}-\mathrm{ERG}$ 접합 전사체 유무와 유형을 확인해야 한다.

\section{참고문헌}

1. Ferro MR, Cabello P, Garcia-Sagredo JM, Resino M, San Roman C, Larana JG. t(16;21) in a Ph positive CML. Cancer Genet Cytogenet 1992;60:210-1.

2. Kanazawa T, Ogawa C, Taketani T, Taki T, Hayashi Y, Morikawa A. TLS/FUS-ERG fusion gene in acute lymphoblastic leukemia with $\mathrm{t}(16 ; 21)(\mathrm{p} 11 ; \mathrm{q} 22)$ and monitoring of minimal residual disease. Leuk Lymphoma 2005;46:1833-5.

3. Shimizu K, Ichikawa H, Tojo A, Kaneko Y, Maseki N, Hayashi Y, et al. An ets-related gene, $E R G$, is rearranged in human myeloid leukemia with $\mathrm{t}(16 ; 21)$ chromosomal translocation. Proc Natl Acad Sci USA 1993;90:10280-4. 
4. Ichikawa H, Shimizu K, Hayashi Y, Ohki M. An RNA-binding protein gene, TLS/FUS, is fused to ERG in human myeloid leukemia with t(16;21) chromosomal translocation. Cancer Res 1994;54:2865-8.

5. Kong XT, Ida K, Ichikawa H, Shimizu K, Ohki M, Maseki N, et al. Consistent detection of TLS/FUS-ERG chimeric transcripts in acute myeloid leukemia with $\mathrm{t}(16 ; 21)(\mathrm{p} 11 ; \mathrm{q} 22)$ and identification of a novel transcript. Blood 1997;90:1192-9.

6. Imashuku S, Hibi S, Sako M, Lin YW, Ikuta K, Nakata Y, et al. Hemophagocytosis by leukemic blasts in 7 acute myeloid leukemia cases with $\mathrm{t}(16 ; 21)(\mathrm{p} 11 ; \mathrm{q} 22)$ : common morphologic characteristics for this type of leukemia. Cancer 2000;88:1970-5.

7. Choi HW, Shin MG, Sawyer JR, Cho D, Kee SJ, Baek HJ, et al. Unusual type of TLS/FUS-ERG chimeric transcript in a pediatric acute myelocytic leukemia with $47, \mathrm{XX},+10, \mathrm{t}(16 ; 21)(\mathrm{p} 11 ; \mathrm{q} 22)$. Cancer Genet Cytogenet 2006;167:172-6.

8. Perrotti D, Bonatti S, Trotta R, Martinez R, Skorski T, Salomoni P, et al. TLS/FUS, a pro-oncogene involved in multiple chromosomal translocations, is a novel regulator of $B C R / A B L$-mediated leukemogenesis. EMBO J 1998;17:4442-55.

9. Prasad DD, Ouchida M, Lee L, Rao VN, Reddy ES. TLS/FUS fusion domain of TLS/FUS-erg chimeric protein resulting from the $t(16$; 21)chromosomal translocation in human myeloid leukemia functions as a transcriptional activation domain. Oncogene 1994;9:3717-29.

10. Imashuku S, Hibi S, Kuriyama K, Todo S. Hemophagocytosis by leukemic blasts in a case of acute megakaryoblastic leukemia with $\mathrm{t}(16 ; 21)(\mathrm{p} 11 ; \mathrm{q} 22)$. Int J Hematol 1999;70:36-9.

11. Shikami M, Miwa H, Nishii K, Tkahashi T, Shiku H, Tsutani H, et al. Myeloid differentiation antigen and cytokine receptor expression on acute myelocytic leukaemia cells with $\mathrm{t}(16 ; 21)(\mathrm{p} 11 ; \mathrm{q} 22)$ : frequent expression of CD56 and interleukin-2 receptor $\alpha$ chain. Br J Haematol 1999;105:711-9.

12. Jekarl DW, Kim YG, Lim JY, Kim MS, Han KJ, Lee AW, et al. CD56 expression and hemophagocytosis of leukemic cells in acute myeloid leukemia with $\mathrm{t}(16 ; 21)(\mathrm{p} 11 ; \mathrm{q} 22)$. Korean J Lab Med 2008;28(S2): S371.

13. Swerdlow SH, Campo E, et al. eds. WHO classification of tumors of haematopoietic and lymphoid tissues. 4th ed. Lyon: International Agency for Research on Cancer, 2008:137.

14. Perot $C$ and Huret JL. eds. Atlas of genetics and cytogenetics in oncology and haematology. http://AtlasGeneticsOncology.org/ Anomalies/t1621.html (Updated on Jan 2005). 